\title{
Business Plans in Bank Decision-Making when Financing new Ventures in South Africa
}

\section{Marius Pretorius and Gordon Shaw}

Chair in Entrepreneurship, University of Pretoria

\section{ABSTRACT}

This article focuses on the position that South African commercial banks adopt when evaluating an application for finance of new business ventures. The role and importance of the business plan in the decision-making process is highlighted and investigated. This article begins to qualitatively describe the decision-making processes, criteria and processes instituted by the four major South African commercial banks that between them serve 96 per cent of the banking services for small business. It then questions the barriers placed on applicants applying for finance and recommends how these barriers can be removed. The article concludes that banks finance business ventures with poor potential for success if the applicant is creditworthy or has the necessary security rather than assist applicants with good plans and ventures with potential, but lacking sufficient security.

JEL G21

\section{INTRODUCTION}

Pretorius and Van Vuuren (2003) state that in South Africa, as in many other countries, the national strategy for the development and promotion of small business identifies small business development and the empowerment of entrepreneurs as the most important avenue for economic growth. Gorman, Hanlon and King (1997: 56) confirm that there is widespread recognition that entrepreneurship is the engine that drives the economy of most nations. Timmons (1999: 4) also refers to entrepreneurship as America's secret weapon and argues its value as the main contributor to the superior position that the USA holds as part of the global economy. He suggests entrepreneurship to be the fundamental difference in the American culture where 37 per cent of the population is somehow involved in their own ventures apart from their regular jobs. 
In South Africa, however, each year brings with it a rush of school and university graduates wanting to enter the job market. This in itself would not pose a problem in a first world country, but in South Africa with its high unemployment figure of over 5.525 million people (representing approximately 29.5 per cent of the labour market), it only adds queues at the employment offices (STATSSA, 2001). The problem is highlighted when the numbers entering the job market are estimated to be in excess of 462,000 potential entrants per annum (Department of Education, 2002). The roughly estimated figure of more than 100000 jobs being lost annually does not improve the situation at all.

When one considers the options open to these unemployed people, entrepreneurship will not only offer employment but will create much needed downstream jobs.

The South African government recognised the dilemma of financing small ventures and as such has implemented a strategy for the development and promotion of SMMEs (small, medium and micro enterprises) in South Africa in February 1995 under the umbrella of the Department of Trade and Industry. From the National Small Business Act 102 of 1996 it appears that the government is clear in its intention of creating small ventures and thereby assisting with the creation of jobs (BSA, 1996).

The thinking is that the only way more jobs can be created is by establishing new businesses and this is where the problem links to financing. Finance is needed in the establishment of new businesses, and the entrepreneur or business owner finds difficulty in obtaining the necessary finance. In many cases, lack of finance is cited as a reason for business failure and non start-up. In South Africa, lack of financial support is the second most reported contributor to startup failure, after education and training (Orford, Wood, Fisher, Herrington \& Segal, 2003: 17).

Nieuwenhuizen (1999: ii) reports in a comprehensive study the criteria to be used for financing of small industrialists. These include seven success factors associated with the personal characteristics of the individual (perseverance, commitment to and involvement in the enterprise, willingness to take risk, sound human relations, creativity and innovation, and a positive attitude and approach) and ten factors that relate to functional management skills (planning of the enterprise, knowledge and skills relating to the enterprise, the use of experts, client service, knowledge of competitors, market orientation, concern for high quality work, bookkeeping for own benefit, financial insight and financial management). Of these 17 success factors financiers use only eight for 
evaluation in general. It may rightly be asked why financiers use so few of these key success factors?

When talking to entrepreneurs, much debate occurs about credit applications accompanied by business plans that are submitted to banks and financial institutions for financing. Few, however, are perceived as successful. The question can rightly be asked ...Why?

It is therefore the intention of this article to explore the reasons why and determine the problems experienced by applicants when applying for finance with commercial banks.

\section{PURPOSE OF THE ARTICLE}

Obtaining finance for the start-up of new ventures has proved to be crucial for SMME growth and is therefore the prime concern of this article. Lack of finance is also generally accepted as the key stumbling block for business startups. This article specifically investigates the role of the business plan as a means to obtain finance from the commercial banks. Foxcroft, Wood, Kew, Herrington and Segal (2002: 41) state that banks are less likely to grant loans than to offer credit via credit cards or overdraft. Only one quarter of applications for bank loans were reported successful in South Africa.

Shaw (2002: 1) confirms this by reporting that the deputy minister of Trade and Industry (DTI), in his 2002 annual report, asked two very important questions:

- What steps can be taken to fill the gap caused by the aversion of the formal banking sector to lending in the SMME sector?

- $\quad$ Related to this, what can be done to change the attitude of banks in South Africa?

These questions highlight the ongoing debate relevant to the financing of SMME's. Development, small business growth, elimination of unemployment etc. are all relevant issues when SMME financing is discussed. This article investigates the importance of producing a business plan when applying for finance from commercial banks as suggested by Berry, Von Blottnitz, Cassim, Kesper, Rajaratnam and Van Seventer (2002).

It is propositioned that banks as financiers look at several different aspects before awarding the finance. The intention is mainly to determine what these aspects are and whether there is a difference between the requirements of the different banking institutions within South Africa. 
All banks require a business plan to accompany applications. When evaluating a business plan, the investor or banking institution will always consider risk as a prime factor, together with management skills and expertise relating to the type of business or venture before committing any funds (Shaw, 2002: 36).

The main contribution of the article is the identification of what really determines the success of the applicants when applying for bank funding. Limited empirical research findings are available on the subject, as it is fairly specific to South Africa.

A secondary benefit is that the findings clarify the role of the business plan in the decision-making criteria of commercial banks. The reason for this is that the banks are accused of discrimination against small businesses and disadvantaged entrepreneurs (Foxcroft et al., 2002: 40).

Another contribution of the findings is that it gives guidance to applicants when they submit business plans, especially about the information critical to the decision-making process of the banks and thereby enhancing the success rate of applications.

Additionally the findings could lead to:

- $\quad$ Time saving - by correctly completing the bank's application documents in detail and having supporting documentation on hand when requested.

- Improved communication and understanding of the full requirements of the bank when applying for finance.

- More applications - the banks would spend less time requesting additional information and therefore have more time to source more deals.

\section{LITERATURE}

\subsection{Business plans - Basic notes}

Throughout the business and academic world, a successful business plan is perceived as the most essential document to be prepared by the entrepreneur or small venture owner when setting up a business. Although many will regard a business plan as a waste of time and money, one must take cognisance of the fact that many of the top 500 United States companies have business plans. Hisrich and Peters (1998: 227) encourage entrepreneurs and small business owners to draw up such a document, as it describes all the relevant external and internal elements involved in starting-up a new business. While a business plan is often obsolete as soon as it is printed, it is an important tool for the entrepreneur as well as the potential financier (Timmons, 1999: 368). 
Entrepreneurs and small business owners are encouraged to prepare a business plan for presentation to banks, financial institutions and venture capitalists to stand a chance of obtaining financial support. Timmons (1999: 368) states the importance of the plan to prospective investors and how they can use it to begin their due diligence. Timmons further postulates that even when negotiations are in an advanced stage, collisions between entrepreneurs and banks occur. The business plan is then used as the guideline for action.

The business plan is an essential document to be used in setting codes and business relationships between the parties. Hisrich and Peters (1998: 225) refer to the business plan as the single most important document when applying for finance at the start-up stage.

This article only identifies the most suitable elements of a business plan and describes the relevant elements as required by the banks before granting finance. For this article, only the basic issues relevant to business plans are listed, as it is not the article's main focus. The literature on business plans show that the main headings to be included in a business plan should cover at least the following: Executive summary, a business description, a marketing plan, a management plan, a financial plan, a manufacturing and operating plan, critical risks description and a future growth and contingency plan (Shaw, 2003: 5).

\subsection{South African financial institutions}

Driver, Wood, Segal, and Herrington (2001) report that South African financial institutions have a history of dealing mainly with large corporations that undertake large projects. Their management skills in handling small businesses were not properly developed as they focused on large businesses with sufficient resources. They also state "fund managers have to show a good return on capital invested" and therefore focus on their own goals rather than that of the entrepreneur. There's a lot of pressure because of that, especially as they are employees of large organisations and they get remunerated as employees. There is often not enough incentive for them to take the risk with a potentially high upside, because at the same time there could be a personal cost for them if they make the wrong investment decision. As a result, the situation moves the financier/investor to be more concerned with the downside risk while entrepreneurs tend to focus more on the upside risk (potential), and at that point the entrepreneurs and financiers miss each other.

Driver et al. (2001) further postulates that banks don't support ventures through a process and would rather lend R200 million to one customer than lend R50 000 to 25000 customers because it is messy, costly and involves too much paperwork for the banks. 
Khula (as a DTI extension) has initiated, since its establishment in 1996, a number of loan schemes to increase access to finance for SMMEs through Retail Financial Intermediaries (RFIs), which are also SMME departments of commercial banks or accredited non government organisations (NGOs). RFI's apply their own minimum lending criteria (the most basic is the provision of a business plan).

\subsection{The South African commercial banking sector}

According to Okeahalam (2001: 9), the four larger banks govern 96 per cent of the small business market segment. The market share distribution of banks in the small business sector is shown in Table 1.

Table 1 Banking services for small business - market shares of major banks (Okeahalam, 2001)

\begin{tabular}{|l|c|c|c|c|c|}
\hline Bank & ABSA & $\begin{array}{c}\text { Standard } \\
\text { Bank }\end{array}$ & $\begin{array}{c}\text { First } \\
\text { National } \\
\text { Bank }\end{array}$ & Nedcor & $\begin{array}{c}\text { Other } \\
\text { banks }\end{array}$ \\
\hline Market share (\%) & 27 & 33 & 19 & 17 & 4 \\
\hline
\end{tabular}

It is hypothesised that the practices of the four major banks will determine the practices for the whole sector and therefore the research is focused on their requirements.

\section{PROBLEM STATEMENT AND PROPOSITIONS}

Entrepreneurs and small business owners who apply for funding are expressing reservations about the availability of finance. The views of the financial institutions are that funds are available but no viable business projects are forthcoming. Initial exploratory investigation, however, indicated that access to finance (start-up and expansion) is the most cited reason for business non startup and failure. What causes concern is the apparent lack of common perception between the parties.

Initial pre-investigation discussions (informal) with financial institutions and entrepreneurs indicated that financiers are not willing to take any risk, however minimal, in funding small business and this triggered the investigation. The findings of Driver et al. (2001: 44) confirm that financial institutions are not able to interact effectively with entrepreneurs, thus supporting this statement. This statement also underlines the importance of the investigation. 
The problem is therefore to establish the extent of the discrepancy between the financier and the entrepreneurial view on access to finance and the role of the business plan in accessing such finance from banks. This article is limited to the four major banks, their procedures and how it could affect potential decisionmaking.

\subsection{Propositions to lead the thinking process}

To investigate the problem as stated above the following propositions were set to govern the thinking during the investigation:

P 1 Banks have clear guidelines for evaluating an application.

If the banks have proper guidelines in place, it is important to understand whether their procedures are not inhibiting successful application and therefore the second proposition is set as:

P 2 Bank application procedures for financing of business ventures are simple to comply with.

Whether the procedures laid down by the banks are simple to comply with or not, it is important to understand the role of the business venture's potential (as described in the business plan) in their assessment and therefore the third proposition is set as:

P 3 The guidelines for selection of a venture for financing are dominated by its potential as described in the business plan.

If the business potential is not dominant in the assessment, it is important to understand the role of other factors such as creditworthiness in the success of the application and therefore the fourth proposition is set as:

P 4 Creditworthiness is the dominant factor in the decision of financing a business.

\section{RESEARCH METHODOLOGY}

A cross sectional, in-depth qualitative investigation was applied to the four major banks (One investigation per bank at head office).

With the recent centralisation within the banks, the investigations were done at the different head offices where credit-granting decisions are mostly taken with a standardised process. A structured questionnaire as described by Shaw (2002: 45) was designed to investigate the salient points during interviews with senior and junior credit managers (at least two per bank) of the four major banks. It was based on the literature on business plan elements to guide the interviewer to 
note the different perceptions, priorities and importance attached to the different issues.

After completion of the investigation and based on the different responses, the interviewees were personally questioned (with open ended questions) to gain indepth knowledge of their perceptions about the relevant issues within their specific bank policies.

Secondly, all applications for finance documents (also those for internal use by the individual banks only) were collected from them and scrutinised and evaluated for length, focus and the degree of difficulty to complete these forms.

Finally, the researcher observed and noted certain reactions of the officials during the interview and has made reference to these potential issues in the findings. Observations included anything not obvious, variations and contradictions in answers, personal opinions and salient issues underlying the statements of the interviewees.

The collected information was categorised firstly for objective versus subjective rating of the criteria used by the bank. Criteria that could be measured (ratios and values) were rated as objective and those where opinion or judgment was the main contribution to the decision was rated as subjective (see also Table 3). Secondly each criterion was rated for its focus on either creditworthiness or potential as shown by the business plan. Each criterion was further rated based on the apparent importance granted to it by the interviewee namely: Mentioned as playing a role $(\mathrm{M})$, focused on strictly by the specific bank $(\mathrm{F})$ or assumed as playing a role too $(\mathrm{A})$.

\section{FINDINGS}

The banks investigated were Nedbank, Absa, Standard Bank and First National Bank, but are referred to as A, B, C, and D (no order) in this article, as confidentiality was promised prior to the investigation to get the different bank personnel to agree to the interviews and investigation. This was done in the hope that more honest opinions would be given. Confidentiality was important firstly to "hear the real truth" and secondly because respondents felt that their "competitive advantage" may be eroded if their specific information is exposed. The focal points examined in the document analysis are shown in Table 2.

While the original investigation was concerned with the differences between banks, this is not necessarily the case for this article because the broader 
economic issue of inability to find financial support surfaced more strongly during the research.

\section{Table 2 Evaluation of bank application documents}

\begin{tabular}{|c|c|c|c|c|}
\hline Bank & A & B & $\mathrm{C}$ & D \\
\hline Length & $\begin{array}{l}11 \text { pages } \\
\text { First six pages } \\
\text { cover personal } \\
\text { and banking } \\
\text { details, } \\
\text { following } 3 \\
\text { pages of } \\
\text { business details } \\
\text { last } 2 \text { pages } \\
\text { relate to } \\
\text { description of } \\
\text { security }\end{array}$ & $\begin{array}{l}11 \text { pages } \\
\text { First three cover } \\
\text { personal and } \\
\text { banking details, } \\
\text { following eight } \\
\text { cover business and } \\
\text { description of } \\
\text { security }\end{array}$ & $\begin{array}{l}\text { No formal } \\
\text { documents to be } \\
\text { completed. Copies } \\
\text { of the following } \\
\text { documents to be } \\
\text { handed to bank; } \\
\text { Business plan, } \\
\text { cash flow } \\
\text { projection for } 12 \\
\text { months, Members } \\
\text { CV’s in detail, } \\
\text { Confirmation of } \\
\text { capital deposit }\end{array}$ & $\begin{array}{l}\text { No application } \\
\text { documents } \\
\text { available for } \\
\text { scrutiny, but there } \\
\text { are internal } \\
\text { documents - } \\
\text { considered } \\
\text { confidential } \\
\text { between client and } \\
\text { bank. Business } \\
\text { plan, cash flow for } \\
12 \text { months, } \\
\text { Personal balance } \\
\text { sheet, Members } \\
\text { CV's, } \\
\text { Confirmation of } \\
\text { capital deposit }\end{array}$ \\
\hline Focus & $\begin{array}{l}\text { Primary banking } \\
\text { and credit card } \\
\text { accounts, } \\
\text { Current } \\
\text { obligations, } \\
\text { statement of } \\
\text { assets and } \\
\text { liabilities, } \\
\text { mortgage bonds, } \\
\text { shares and other } \\
\text { investments, life } \\
\text { policies, sureties } \\
\text { and contingent } \\
\text { liability leases }\end{array}$ & $\begin{array}{l}\text { Personal details, } \\
\text { current obligations, } \\
\text { statement of assets } \\
\text { and liabilities, fixed } \\
\text { property, other } \\
\text { movable assets, } \\
\text { overdrafts/loans, } \\
\text { income and } \\
\text { expenditure } \\
\text { statement, } \\
\text { insurance policies, } \\
\text { sureties and } \\
\text { contingent liability } \\
\text { leases }\end{array}$ & $\begin{array}{l}\text { Business plan } \\
12 \text { month cash } \\
\text { flow projections } \\
\text { Members CV's } \\
\text { Confirmation of } \\
\text { cash deposit }\end{array}$ & $\begin{array}{l}\text { Business plan } \\
12 \text { month cash } \\
\text { flow projection } \\
\text { Personal balance } \\
\text { sheets } \\
\text { Members CV's } \\
\text { Confirmation of } \\
\text { cash deposit }\end{array}$ \\
\hline $\begin{array}{l}\text { Difficul- } \\
\text { ty to } \\
\text { complete }\end{array}$ & \multicolumn{2}{|c|}{$\begin{array}{l}\text { Due to the preciseness of the } \\
\text { information, it is advisable to engage } \\
\text { the services of an accountant or } \\
\text { attorney to assist with the completion } \\
\text { of the documents }\end{array}$} & $\begin{array}{l}\text { Full assistance is } \\
\text { provided by the } \\
\text { client services of } \\
\text { the bank }\end{array}$ & $\begin{array}{l}\text { Full assistance is } \\
\text { provided by the } \\
\text { client services of } \\
\text { the bank }\end{array}$ \\
\hline
\end{tabular}

The process and procedures for application and documentation of each bank follows similar routes with the difference mainly found in the checking (control) of the documents. Two of the banks allow their branches to check for creditworthiness and security prior to sending final documents to head office. The other two banks do all the relevant checks at head office. 


\subsection{Application processes and evaluation criteria}

Once the applicant has completed the documentation, the departments within the bank handle the documents as shown in Figure 1. It shows clearly that the application documents for finance are generally received by a SMME consultant at branch level, which in the case of two of the banks are then sent to the branch credit department for credit approval while the other two banks conduct the necessary credit checks at head office. If approved, this approved application, together with the business plan, is forwarded to Khula for the issuing of the government program guarantees. Khula plays a role mostly when the application is weak, while the banks will fund stronger applications without the Khula guarantee. Applications not passing credit approval are returned to the SMME consultant for additional information and any other detail that may improve the credit status of the application. Alternatively the application is rejected. Table 3 describes the criteria evaluated by each bank and shows the different focuses as well as the similarities between them.

\section{Figure 1 Generic route followed by application documentation through} the various banks (Compilation based on responses)

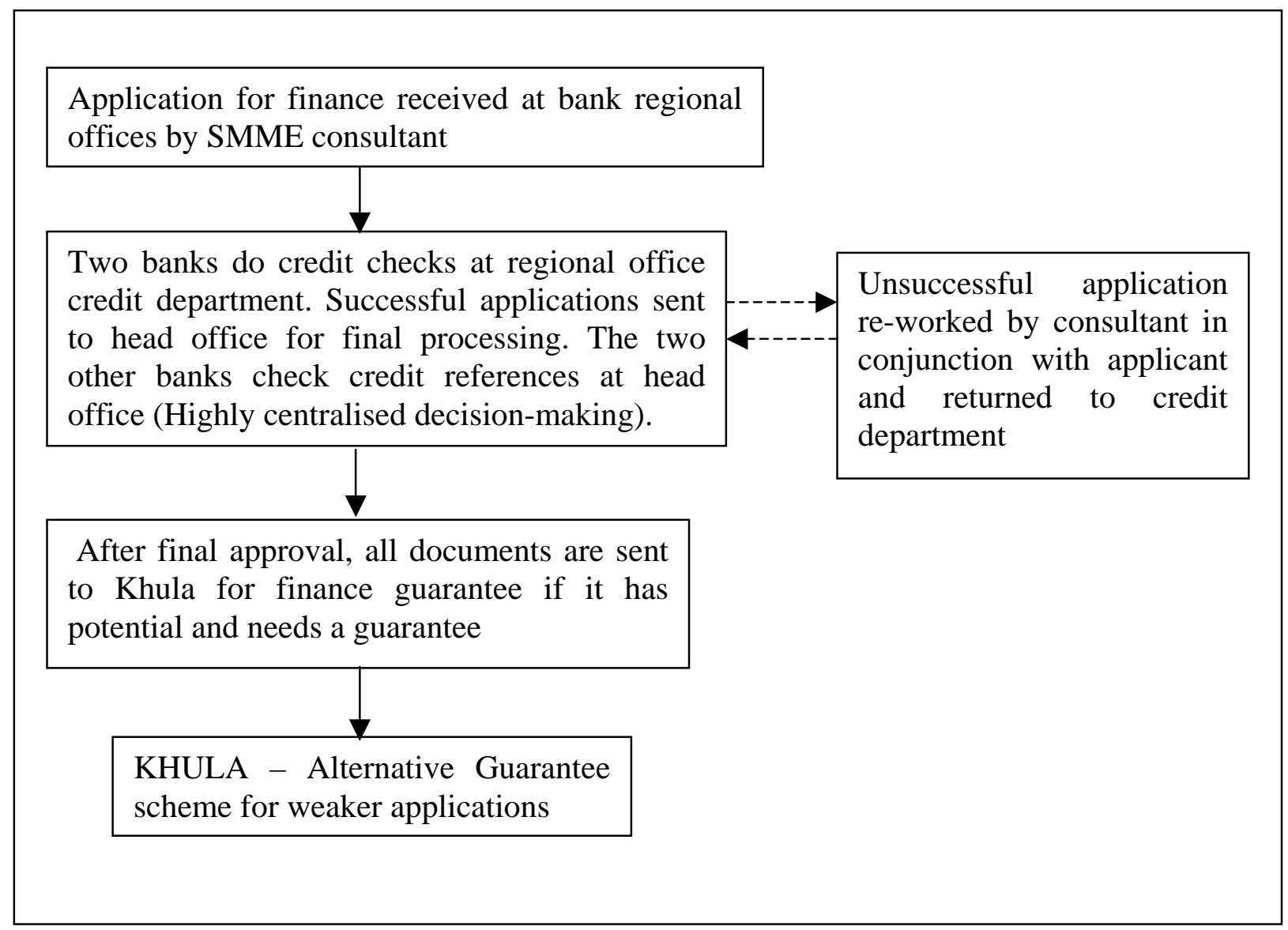




\section{Table 3 Summary of the comparison of the different criteria used for selection for financing by different banks}

\begin{tabular}{|c|c|c|c|c|c|c|c|}
\hline \multirow[t]{2}{*}{ Bank } & \multirow[t]{2}{*}{ Criteria scrutinised } & \multirow{2}{*}{$\begin{array}{l}\text { Objectively/ } \\
\text { subjectively } \\
\text { measured }\end{array}$} & \multirow{2}{*}{$\begin{array}{l}\text { Primary } \\
\text { focus }\end{array}$} & \multicolumn{4}{|c|}{ Banks } \\
\hline & & & & $\mathbf{A}$ & $\mathbf{B}$ & $\mathrm{C}$ & $\mathbf{D}$ \\
\hline A & $\begin{array}{l}\text { All application for finance documents to } \\
\text { be completed in great detail. }\end{array}$ & $\mathrm{S}$ & & $\mathrm{F}$ & & & \\
\hline A & $\begin{array}{l}\text { Creditworthiness of owner, obtained by } \\
\text { completion of a detailed credit } \\
\text { application form, listing assets and } \\
\text { liabilities. }\end{array}$ & $\mathrm{O}$ & Credit & $\mathrm{F}$ & & & \\
\hline $\mathrm{A}$ & $\begin{array}{l}\text { Asset values, properties registered in } \\
\text { owner's name, stock, vehicles, shares } \\
\text { and unlisted shares receive high priority. }\end{array}$ & $\mathrm{O}$ & Credit & F & $\mathrm{F}$ & & \\
\hline $\mathrm{A}$ & $\begin{array}{l}\text { Owner's uninhibited cash contribution } \\
\text { (funds not allocated for other purposes). }\end{array}$ & $\mathrm{O}$ & Credit & F & & & \\
\hline A & $\begin{array}{l}\text { Cash flow projection and financial plan, } \\
\text { including the following: turnover, cost } \\
\text { of sales, gross profit (turnover minus } \\
\text { cost of sales), royalty payments, bank } \\
\text { repayments, and net profit after loan } \\
\text { repayment. }\end{array}$ & $\mathrm{O}$ & Credit & $\mathrm{F}$ & $\mathrm{F}$ & & \\
\hline A & $\begin{array}{l}\text { Marketing plan, place, promotion, price } \\
\text { and competition. }\end{array}$ & $\mathrm{S} / \mathrm{O}$ & $\begin{array}{l}\text { Potential of } \\
\text { plan }\end{array}$ & $\mathrm{F}$ & $\mathrm{M}$ & & \\
\hline $\mathrm{A}$ & $\begin{array}{l}\text { "What-if" proposal, or contingency } \\
\text { plan. The ability to keep the business on } \\
\text { track whatever happens. }\end{array}$ & $\mathrm{S} / \mathrm{O}$ & $\begin{array}{l}\text { Potential of } \\
\text { plan }\end{array}$ & F & & & \\
\hline A & $\begin{array}{l}\text { When all criteria are finally analysed, } \\
\text { the approval is dependent on the } \\
\text { owner's creditworthiness, assets value } \\
\text { (collateral) and the availability of } \\
\text { uninhibited funds to be used as deposit. }\end{array}$ & $\mathrm{O}$ & Credit & $\mathrm{F}$ & & & \\
\hline $\mathrm{B}$ & $\begin{array}{l}\text { Business plan must be well constructed } \\
\text { and workable. }\end{array}$ & $S$ & - & $\mathrm{M}$ & $\mathrm{F}$ & & \\
\hline $\mathrm{B}$ & $\begin{array}{l}\text { Cash flow projection must be well } \\
\text { prepared and must contain the } \\
\text { following; overdraft at beginning of } \\
\text { month, cash sales, collections from } \\
\text { debtors, draws on loans, discounts, fixed } \\
\text { overheads, variable expenses, payments } \\
\text { to suppliers, loan repayments, purchases } \\
\text { of fixed assets, tax payments, } \\
\text { surplus/shortfall and overdraft at end of } \\
\text { month. }\end{array}$ & $\mathrm{S} / \mathrm{O}$ & $\begin{array}{l}\text { Potential of } \\
\text { plan }\end{array}$ & $\mathrm{F}$ & $\mathrm{F}$ & & \\
\hline $\mathrm{B}$ & $\begin{array}{l}\text { Marketing plan must be realistic, } \\
\text { prepared for } 1,3 \text { and } 5 \text { years, must } \\
\text { include price, promotion, place and } \\
\text { competition }\end{array}$ & S & $\begin{array}{l}\text { Potential of } \\
\text { plan }\end{array}$ & & $\mathrm{F}$ & & \\
\hline
\end{tabular}


Table 3 continued

\begin{tabular}{|c|c|c|c|c|c|c|c|}
\hline \multirow[t]{2}{*}{ Bank } & \multirow[t]{2}{*}{ Criteria scrutinised } & \multirow{2}{*}{\begin{tabular}{|l|} 
Objectively/ \\
subjectively \\
measured
\end{tabular}} & \multirow{2}{*}{$\begin{array}{l}\text { Primary } \\
\text { focus }\end{array}$} & \multicolumn{4}{|c|}{ Banks } \\
\hline & & & & A & & & \\
\hline B & $\begin{array}{l}\text { Competent management structure, } \\
\text { skills, training, previous management } \\
\text { positions, where and position held. }\end{array}$ & $\mathrm{S}$ & $\begin{array}{l}\text { Potential of } \\
\text { plan }\end{array}$ & & $\mathrm{F}$ & & \\
\hline $\mathrm{B}$ & $\begin{array}{l}\text { Securities and guarantees are checked, } \\
\text { to ensure guarantees are uninhibited. }\end{array}$ & $\mathrm{O}$ & Credit & F & $\mathrm{F}$ & & \\
\hline $\mathrm{C}$ & $\begin{array}{l}\text { Check failure rate of businesses in the } \\
\text { area, the bank has in the past } \\
\text { experienced problems pertaining to } \\
\text { certain types of businesses in different } \\
\text { areas. }\end{array}$ & $\mathrm{S} / \mathrm{O}$ & $\begin{array}{l}\text { Potential of } \\
\text { plan }\end{array}$ & & & $\mathrm{F}$ & \\
\hline $\mathrm{C}$ & $\begin{array}{l}\text { Understanding that the applicant is "au } \\
\text { fait" with the contents of the document. }\end{array}$ & $\mathrm{S}$ & $\begin{array}{l}\text { Potential of } \\
\text { plan }\end{array}$ & & & $\mathrm{F}$ & \\
\hline $\mathrm{C}$ & $\begin{array}{l}\text { Ensure that the project is feasible: Banks } \\
\text { have received many projects that are } \\
\text { feasible in the minds of the applicant } \\
\text { but, due to demographics and } \\
\text { competition, are not deemed to be } \\
\text { feasible to the bank. }\end{array}$ & $\mathrm{S} / \mathrm{O}$ & $\begin{array}{l}\text { Potential of } \\
\text { plan }\end{array}$ & & & $\mathrm{F}$ & \\
\hline $\mathrm{C}$ & $\begin{array}{l}\text { Check cash flow projections: Ensure } \\
\text { that the projections will allow for a } \\
\text { monthly/ annual breakeven. }\end{array}$ & $\mathrm{S} / \mathrm{O}$ & $\begin{array}{l}\text { Credit and } \\
\text { Potential of } \\
\text { plan }\end{array}$ & $\mathrm{F}$ & $\mathrm{F}$ & $\bar{F}$ & \\
\hline $\mathrm{C}$ & $\begin{array}{l}\text { Check demographics, location, access, } \\
\text { transport and security. }\end{array}$ & $\mathrm{S}$ & $\begin{array}{l}\text { Potential of } \\
\text { plan }\end{array}$ & & & $\mathrm{F}$ & \\
\hline $\mathrm{C}$ & $\begin{array}{l}\text { Personal visit to area by bank } \\
\text { management team, the area is a place on } \\
\text { the map. Only by personal visits by the } \\
\text { bank personnel can they make an } \\
\text { accurate assessment of the prevailing } \\
\text { situation. }\end{array}$ & $S$ & $\begin{array}{l}\text { Potential of } \\
\text { plan }\end{array}$ & & & $\mathrm{F}$ & \\
\hline $\mathrm{D}$ & $\begin{array}{l}\text { Owner investment: It is considered } \\
\text { extremely important to have the } \\
\text { applicant invest personal funds into the } \\
\text { business. }\end{array}$ & $\mathrm{O}$ & Credit & $\mathrm{A}$ & $\mathrm{A}$ & A & F \\
\hline $\mathrm{D}$ & $\begin{array}{l}\text { Management: A successful business is } \\
\text { managed and lead by a successful } \\
\text { management team, necessary to ensure } \\
\text { the past experiences of the team, by } \\
\text { reference checking and ensuring } \\
\text { certificates, diplomas and degrees are } \\
\text { authentic }\end{array}$ & S & $\begin{array}{l}\text { Potential of } \\
\text { plan }\end{array}$ & & $\mathrm{M}$ & & $\mathrm{F}$ \\
\hline $\mathrm{D}$ & $\begin{array}{l}\text { Collateral offered in the owner's name: } \\
\text { Must be in the name of the owner and } \\
\text { must be uninhibited. }\end{array}$ & $\mathrm{O}$ & Credit & & & & $\mathrm{F}$ \\
\hline
\end{tabular}


Table 3 continued

\begin{tabular}{|c|c|c|c|c|c|c|c|}
\hline \multirow[t]{2}{*}{ Bank } & \multirow[t]{2}{*}{ Criteria scrutinised } & \multirow{2}{*}{$\begin{array}{l}\text { Objectively/ } \\
\text { subjectively } \\
\text { measured }\end{array}$} & \multirow{2}{*}{$\begin{array}{l}\text { Primary } \\
\text { focus }\end{array}$} & \multicolumn{4}{|c|}{ Banks } \\
\hline & & & & A & B & C & $\mathbf{D}$ \\
\hline $\mathrm{D}$ & $\begin{array}{l}\text { Business plan must be read and } \\
\text { understood by the applicant from a } \\
\text { macro perspective, referring to the type } \\
\text { and nature of business being undertaken } \\
\text { and if all facets of the plan have been } \\
\text { implemented. }\end{array}$ & $\mathrm{S}$ & $\begin{array}{l}\text { Potential of } \\
\text { plan }\end{array}$ & & & $\mathrm{F}$ & $\mathrm{F}$ \\
\hline All & $\begin{array}{l}\text { Proper research into all aspects of the } \\
\text { business has been thoroughly done by } \\
\text { applicant and that the numbers add up. }\end{array}$ & $\mathrm{S} / \mathrm{O}$ & $\begin{array}{l}\text { Potential of } \\
\text { plan }\end{array}$ & A & A & A & $\mathrm{F}$ \\
\hline All & $\begin{array}{l}\text { Realistic projections and that all } \\
\text { eventualities have been taken into } \\
\text { account }\end{array}$ & $\mathrm{S} / \mathrm{O}$ & $\begin{array}{l}\text { Potential of } \\
\text { plan }\end{array}$ & A & A & A & $\mathrm{F}$ \\
\hline \multicolumn{8}{|c|}{ Summary for all banks } \\
\hline & Elements subjectively evaluated & $36(\%)$ & & & & & \\
\hline & Elements objectively evaluated & $32(\%)$ & & & & & \\
\hline & Elements in both categories & $32(\%)$ & & & & & \\
\hline & \multicolumn{2}{|l|}{ Creditworthiness focus } & $34.7(\%)$ & & & & \\
\hline & \multicolumn{2}{|l|}{ Potential of the plan focus } & $60.8(\%)$ & & & & \\
\hline & \multicolumn{2}{|l|}{ Both } & $4.3(\%)$ & & & & \\
\hline
\end{tabular}

$\mathrm{M}=$ Mentioned as playing a role, $\mathrm{F}=$ Focused on strictly by bank, $\mathrm{A}=$ Assumed as playing a role too. $\mathrm{S}=$ subjectively measured, $\mathrm{O}=$ Objective measured with criteria, Credit $=$ Focus on creditworthiness and payback potential, $\mathrm{P}=$ Focus on the business potential as described in the business plan.

Table 4 Case and percentage comparison of the creditworthiness vs potential of the business focus and subjective and objective measurement thereof (Base data from Table 3)

\begin{tabular}{|l|c|c|c|c|}
\hline Measurement & Objective & Both & Subjective & Total \\
\hline Focus & 8 & 0 & 0 & $\begin{array}{c}8 \\
(34.4 \%)\end{array}$ \\
\hline Creditworthiness focus & 0 & 1 & 0 & $\begin{array}{c}1 \\
(4.3 \%)\end{array}$ \\
\hline Potential of the plan focus & 0 & 7 & 7 & $\begin{array}{c}14 \\
(60.8 \%)\end{array}$ \\
\hline Total & $\begin{array}{c}8 \\
(34.7 \%)\end{array}$ & $\begin{array}{c}8 \\
(34.7 \%)\end{array}$ & $\begin{array}{c}7 \\
(30.4 \%)\end{array}$ & 23 \\
\hline
\end{tabular}


Table 4 shows a grid that indicates that all objective measurements were focused on creditworthiness while most subjective measurements had to do with the potential of the plan (although not statistically proven). There seems to be an attempt to use objective measurements for the evaluation of the business potential but it seems overweight on the subjective side instead.

\subsection{Interesting issues mentioned during interviews}

An interesting comment made by the senior credit manager of one of the banks was about the importance of the funds needed to start the business. A recurring problem for the bank was that applicants were budgeting too low in the initial stages and had to keep re-applying for additional funds.

Another bank suggested that they "find more reasons to say yes rather than no to clients”, a commendable but potential marketing focused statement. The banks further mentioned that applicants were paying consultants to write a business plan on their behalf, while not participating in its content. This is obvious as seen in the similarities in business plans submitted over a period of time. This practice is unwarranted and weighs negatively on the application. Underestimation of the financial needs comes up frequently as a problem as mentioned before. This seems to be a shortcoming in terms of applying for finance and should be addressed during the initial interview with the consultants.

\subsection{Evaluation of relevant issues that should be included in the business plan}

After completion of the interviews at the various banks, comparisons were made relating to each individual question. The findings considering the potential of the venture are discussed in an abridged form highlighting the prominent features.

Support research (of which the detail is not reported for lack of space) further indicated that each of the banks rated location, market research and the financial plan as being extremely important. The management team and the marketing plan are high on the list of priorities as confirmed by Table 3, while the executive summary receives a lessor priority despite being the most read part of the plan. This may be important information for potential applicants when writing a business plan for obtaining finance from banking institutions and should definitely be included.

The industries that were rated as preferential by respondents were manufacturing, wholesale, retail, service industry, transport sector and the IT 
industry. It is interesting to note the apparent preference that the banks place on the service and IT industries, although there are no definite/clear preferences.

Different elements that support the business plan by adding value to it was issues such as: signed contracts, license agreements, franchise agreements, patents and copyright. While everyone is calling for job creation, it is surprising to note that this item is not near the top of the priorities when consideration is made for finance.

The banks do not indicate a preference when it comes to rural or urban locations for positioning a business, although one bank investigates the failure of businesses in the specific area as part of their decision-making. They also considered a formal address as important by reasoning that it is needed before granting any funds.

From the list of business sites namely business hives, industrial areas, metropolitan areas, office blocks or suburban shopping centres/malls, the preferred locations indicated by the banks were suburban shopping malls because of the number of feet (traffic) entering such malls. Surprisingly metropolitan areas received a low preference rating, which could be ascribed to the perceived higher rate of crime associated with these areas.

All four banks concur that applicants tend to underestimate the funds needed at the start-up of a business. Access to markets as well as lack of skilled labour and weak management skills tend to be important for all banks.

Asked how important environmental issues, technical advantages, policy and regulatory issues and business / product life cycle are in the granting of funds the banks were all in agreement that the political environment played the most important role despite it being stable and currently not considered a problem. The banks do not rate the business and product life cycles as important.

\subsection{Evaluation of findings}

The aim of the research was to gain understanding of how the banks in South Africa evaluate business plans that are offered to them when potential small business entrepreneurs apply for finance to fund their ventures. Revisiting the propositions guides the thinking and evaluation of the findings. Based on the aggregate responses of the four major South African banks, the following propositions were supported or not:

From the findings it seems that a business plan is claimed to be an essential requirement by the major banks. Each individual bank does, however, place 
certain (and sometimes different) priorities on different sections of the business plan. Overall the financial and management structures of individual institutions play a significant role in the final decision-making. Added to the business plan are the extensive application forms that must be completed and therefore the first proposition can be supported that the banks do have clear guidelines for evaluation of applications. Each bank, however, seems to have its own focuses when granting the finance.

Table 3 shows the diversity that exists between banks for documents and the focuses of each. What should be considered is that many of the criteria are subjective in nature; especially criteria used to evaluate the potential of the business are mostly subjective compared to the objective criteria that are used to evaluate issues of creditworthiness and financial projections. Therefore the next proposition becomes relevant.

Considering all the complicated documentation (See Table 2) and financial requirements requested by the banks, together with the unencumbered assets and cash required as deposit, makes the procedures lengthy and at times not linked to the business plan. The second proposition is therefore not supported and it is stated that the application procedures for financing are not simple to comply with.

The question can now rightly be asked whether this serves as a purposeful deterrent for applications and if so, what is the magnitude thereof? Despite this, some applications proceed through the process leading to the next proposition.

The research has shown that in essence, the acceptance for financing of the business comes overwhelmingly down to creditworthiness and how much the applicants are able to finance from own sources. No matter how good the venture looks on paper, what really counts is how much capital the applicant can put down in cash, so as to limit the financial risk to the bank. The third proposition is therefore not supported, based on the evidence of this research and it is accepted that the guidelines for selection are not dominated by the business potential as described in the business plan. It should be stated that the business plan plays a secondary role when and if the creditworthiness requirement test is passed.

Tables 3 and 4 indicate that despite the evaluation for potential of the venture, the criteria for success is mostly subjective except for those related to financial issues that are objectively evaluated. Therefore, it is much easier to use the standards as set by ratios such as financial contribution and a debt:equity ratio, for example, to discriminate with rather than evaluating the potential of the venture. Potential is hard to determine due to the many elements to be 
considered. It is also easier for unqualified people to rate an application based on predetermined ratios while evaluating business potential required experience and knowledge beyond the average found in bank employees. The fourth proposition, that creditworthiness is the dominant factor, then becomes even more relevant.

These results have shown that the banks in general appeared to take cognisance of business plans, all calling for relatively similar criteria. Their decisions were, however, firstly based on the same standard, namely if you have the creditworthiness and collateral, they will extend a loan. Based on this evidence, the fourth proposition that creditworthiness is the dominant factor in the financing decision is supported.

It seems that despite Khula being the risk underwriters to the banks and while banks consult with Khula to find a way to make finance easier for applicants, at present, banks are still extremely stringent in the checking of credit requirements, assets and liabilities and creditworthiness before forwarding an application to Khula for the granting of credit. It appears that they are still overly risk averse and the reasons for this appears to be twofold:

The time delay in receiving Khula's guarantee of funds, should the business go insolvent

The difficulty to obtain the guarantee from Khula paid to the bank in case of default (These are explored in a follow-up paper).

\section{DISCUSSION AND RECOMMENDATIONS}

Khula (the SA government retail funding body) state that they have a mandate to ensure that the people of the country, especially the less privileged and previously disadvantaged, have ready access to the tools and resources that will allow them to create wealth for themselves by forming SMMEs. Khula has an expectation about the contribution of the banks to this goal.

Tati (2002: 9) reflects on the banks that are experiencing as he puts it "a torrid and disruptive period”. He refers to recent problems such as Saambou's demise; the problems at BOE bank and the rejection of the proposed take-over of Standard Bank by Nedcor by the Minister of Finance. These issues were taking preference over the financial needs of applicants applying for finance. He suggests that these factors had a disruptive influence and have impacted on the relationship with the banks, in so far as the progress made with the small business units in the banks have suffered as a result of these events, and that 
these units being highly vulnerable, were the first to be shut down. He further believes that the small group of skilled and knowledgeable people in the field of small business lending are now also lost to the finance industry and will find employment in other fields (Tati, 2002: 9).

After all is said, the government who is a key role player is calling for more businesses to be created resulting in more jobs. The rejection of a business plan because of the non-availability of the required deposit could and should be overcome in instances of potentially good business ventures with growth possibilities. Given the politically based history of South African banks the issue is also contentious.

The results have shown that in essence the business plan forms the foundation of turning a good business idea into an opportunity. The banks, however, are reluctant to pass any deal on the strength of a business plan without having sufficient collateral and knowing the applicant is creditworthy.

The findings for each bank were reported individually but there were many similarities when a comparison was made. While the overall evaluation procedures and criteria observed between the banks were not too far apart, the understanding is that assets and owner creditworthiness were of utmost importance to each of the institutions.

This article focuses on the entrepreneur / small businessperson applying for a loan and it is, therefore, important to understand that the applicant often is someone with limited business and entrepreneurial skills or one that is probably going into business for the first time and mostly is in need of finance for the start-up. This is especially the case for micro level business ventures.

One fairly shocking confirmation from the informal comments of interviewees was that it appears that several feasible applications have been rejected because the applicants did not have the necessary deposits, irrespective of the business potential.

The question that now arises is how many poor potential ventures with creditworthy applicants failed? In the end the entrepreneurs lost everything but the banks got their investment back because they did not take any risk.

Proposed in Figure 2 is a simple model to underscore the differences between the perspectives of banks and entrepreneurs that may underlie the problem. Typically, if the intersection can be increased, there will be more space for success. At the point that this study was completed, however, there appears to be a gap between the banks and the entrepreneurs despite certain measures such 
as Khula's guarantee scheme implemented by the government. It is clear that there appears to be little within the intersection between the two sides.

Given the importance of this issue, banks should perhaps seek more alternatives to move closer to the entrepreneur. Other measures such as the creation of an additional fund (deposit assistance) that can finance the required deposit of good business plans could be investigated.

It seems that the individual banks will always control the decision when vetting each individual business plan and would therefore only recommend poorer business plans they do not deem viable for funding to Khula for guarantees. Additionally, trained and competent staff at Khula, who can arrange the finance with an approved and participating bank, should evaluate the application for finance and the business plan. There is also a need to investigate and streamline the process used by the banks to obtain refunds from Khula, in the case of defaulters or bankruptcy. Currently this process is rated as taking too long. This may be an important reason for banks still being stringent on credit rather than considering alternative merits.

As business plans are vital to the start-up of a business, it is important to ensure they are correctly compiled and contain all the relevant information that will encourage the banks to retain interest in the business, and assist in bringing the business to fruition, as far as possible. To alleviate the problem of banks hiring additional staff, Khula could assist in having suitably qualified consultants present during the initial encounter with the entrepreneur/businessperson and the banks. Further it must be ensured that business plans are correctly compiled.

This might in the first place help to expedite the application process and encourage more applicants to apply for finance, which will in turn produce more small businesses and in so doing, produce the much-needed increase in job numbers.

Further investigation is needed to find methods and ways to ensure that the banks, with or without Khula assistance, assist the entrepreneur in drawing up a business plan that contains the necessary business ingredients needed for being successful.

The findings seem to be in line with Driver et al. (2001: 45) in their finding about the banking institutions in South Africa when they state "Twenty years ago bank managers in small towns had their own independence. Now everything in terms of credit control is centralised, and the last thing a computer thinks of is character. It is all done on assets, if you don't have assets you don't get credit”. The findings reported in this article are in support of this statement. 
Based on the findings, it can be concluded that although the banks all ask for a business plan to be submitted when applying for credit, the final decision comes down to the creditworthiness of the business owner and the extent of his/her guarantees. Creditworthiness or own contribution / guarantees are further used as a basic screening tool long before the business plan is relevant. The business plan therefore becomes relevant only if the above "minimum requirements" are satisfied.

Figure 2 Difference in the perception of needs for banks and entrepreneurial applicants when applying for funding

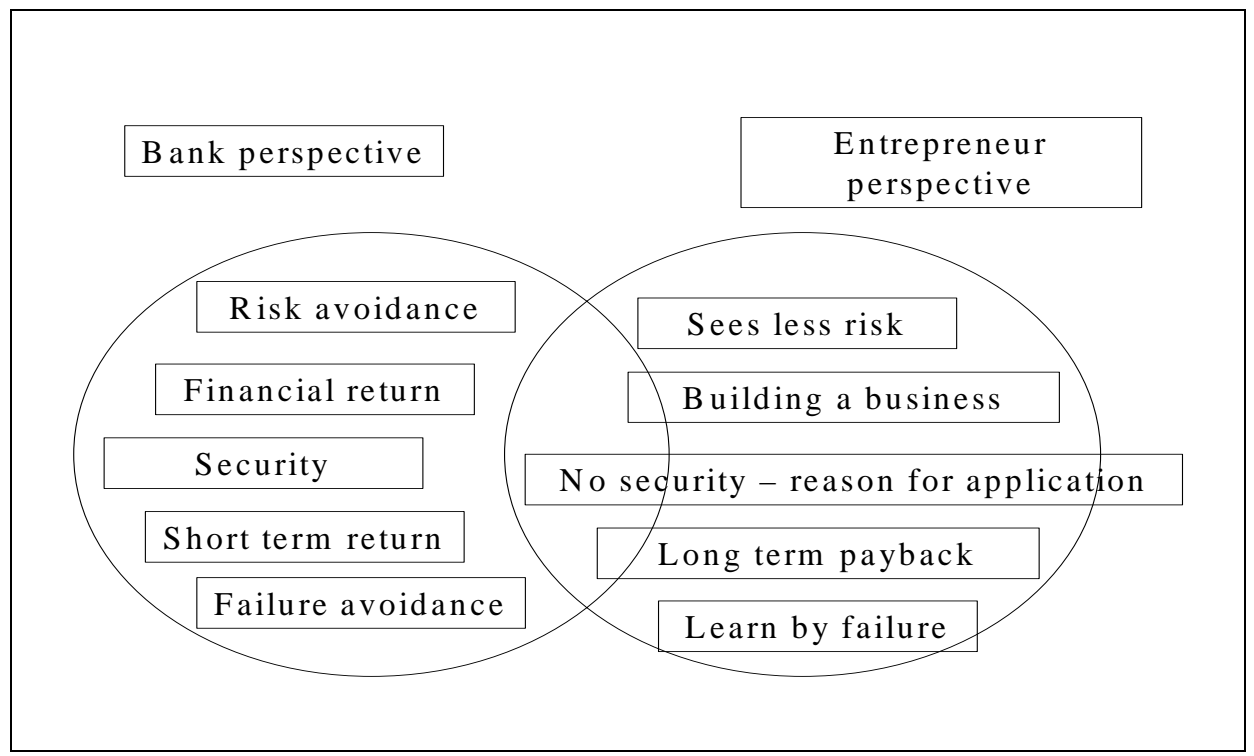

The final question that arises concerns the ability of those who evaluate the business plans to determine potential and their ability to do so. Nieuwenhuizen (1999: 2) asked this question before. Generally, this ability is not easily found and therefore the banks have mostly centralised their vetting capacity. Is it focused on measurable credit parameters because the banks do not have the capacity to evaluate business potential meaningfully? This warrants further investigation.

\section{REFERENCES}

1 BERRY, A., VON BLOTTNITZ, M., CASSIM, R., KESPER, A., RAJARATNAM, B. \& VAN SEVENTER, D.E. (2002) "The economics of SMME's in South Africa”, www.tips.org.za (Accessed on16/09/02).

2 DEPARTMENT OF EDUCATION (2002) "Improvements in the Senior Certificate Examination”, http://Education.pwv.gov.za Accessed 4/01/03. 
3 DRIVER, A., WOOD, E., SEGAL, N. \& HERRINGTON, M. (2001) Global Entrepreneurship Monitor, Graduate School of Business. Cape Town. www.gemconsortium.org.

4 FOXCROFT, M., WOOD, E., KEW, J., HERRINGTON, M. \& SEGAL, N. (2002) Global Entrepreneurship Monitor, South African Executive Report. Graduate School of Business. Cape Town. www.gemconsortium.org.

5 GORMAN, G., HANLON, D. \& KING, W. (1997) "Some research perspectives on entrepreneurship education, enterprise education and education for small business management”, International Small Business Journal, 15(3) 56-77.

6 HISRICH, R.D. \& PETERS, M.P. (1998) Entrepreneurship, (4 ${ }^{\text {th }}$ ed.) McGraw-Hill: Boston.

7 NIEUWENHUIZEN, C. (1999) "Kriteria vir die finansiering van kleinnyweraars", PhD thesis. Potchefstroom University for CHO.

8 OKEAHALAM, C.C. (2001) "Structure and conduct in the commercial banking sector of South Africa”, Paper presented at the TIPS 2001 Annual Forum.

9 ORFORD, J., WOOD, E., FISHER, C. HERRINGTON, M. \& SEGAL, N. (2003) Global Entrepreneurship Monitor. UCT Graduate School of Business. www.gsb.uct.ac.za/cie.

10 PRETORIUS, M \& VAN VUUREN, J.J. (2003) “The contribution of support and incentive programs to entrepreneurial orientation and start-up culture in South Africa”, South African Journal of Management Sciences 6(3): 521-35.

11 SHAW, G.K. (2002) "Decision-making processes of commercial banks in financing new ventures: The role of the business plan" $M$ Phil dissertation, University of Pretoria: Pretoria.

12 SOUTH AFRICA. National Small Business Act (1996) No. 102. Government Printer: Cape Town.

13 STATSSA (Statistics South Africa) (2002) Labour Force Survey: Pretoria www.statssa.gov.za (Accessed on16/9/2002).

14 TATI, S. (2002) Khula Enterprise Finance Ltd-Annual Report 20012002, $\quad$ http://www.khula.org.za/divisions_credit_individual.html (Accessed on 29/09/2002).

15 TIMMONS, J.A. (1999) New Venture Creation, (5 ${ }^{\text {th }}$ ed.) McGraw-Hill: Boston. 